\title{
Vacuum distillation residue upgrading by an indigenous Bacillus cereus
}

\author{
Mitra Sadat Tabatabaee ${ }^{1}$ and Mahnaz Mazaheri Assadi ${ }^{2^{*}}$
}

\begin{abstract}
Background: Biological processing of heavy fractions of crude oils offers less severe process conditions and higher selectivity for refining. Biochemical Processes are expected to be low demand energy processes and certainly ecofriendly.

Results: A strain of biosurfactant producing bacterium was isolated from an oil contaminated soil at Tehran refinery distillation unit. Based on selected phenotypic and genotypic characteristic including morphology, biochemical proprety, and 16 SrRNA sequencing identified as a novel strain of Bacillus cereus (JQ178332). This bacterium endures a wide range of $\mathrm{pH}$, salinity and temperature. This specific strain utilizes both paraffin and anthracene as samples of aliphatic and polycyclic aromatic hydrocarbons. The ability of this bacterium to acquire all its energy and chemical requirements from Vacuum Distillation Residue (VR), as a net sample of problematic hydrocarbons in refineries, was studied. SARA test ASTM D4124-01 revealed 65.5\% decrease in asphaltenic, 22.1\% in aliphatics and 30.3\% in Aromatics content of the VR in MSM medium. Further results with $0.9 \%$ saline showed $55 \%$ decrease in asphaltene content and 2.1\% Aromatics respectively.
\end{abstract}

Conclusion: Remarkable abilities of this microorganism propose its application in an ecofriendly technology to upgrade heavy crude oils.

Keywords: Vacuum distillation residue, Contaminated soil, Crude oil, Bacillus cereus, Upgrading

\section{Background}

Heavy crude oils (bitumen) are extremely viscous and make up of asphaltene, waxes, resins and polycyclic heteroaromatic hydrocarbons containing sulfur and nitrogen. These properties of heavy crude oil and also strict laws of environmental protection make it important for refiners to convert heavier oils into lighter and more valuable products efficiently in very strict operational conditions. Depleting light crude oil reservoirs, scientific interests increase to utilize the vast sources of unconventional crude oil which are heavy and full of problematic components [1-3].

Vacuum distillation residue (VR), the end product of crude oil distillation including high molecular weight $\mathrm{PAH}$, asphaltenic components and waxes $[4,5]$ is a net sample of problematic components of heavy crude oil for laboratory experiments $[6,7]$.

\footnotetext{
* Correspondence: mahnazmazaheri@gmail.com

Environmental Biotechnology, Biotechnology Department, Iranian Research Organization for Science and Technology, Tehran, Iran

Full list of author information is available at the end of the article
}

Since biological processing of heavy crude oil may offer less severe processing conditions in refineries and higher selectivity to specific reactions to increase net distillates, it is proposed that the microorganisms capable to biodegrade heavy fractions of VR, could present an applicable opportunity for upgrading heavy crude oils [8-10].

Bactria able to biodegrade various components of petroleum hydrocarbons such as poly-nuclear aromatic hydrocarbons (PAHs), like anthracene, monoaromatic hydrocarbons such as toluene, or aliphatic hydrocarbons such as $n$-alkanes, are widely reported, particularly from petroleum-contaminated sites [3,11-14]. But there are few reports on isolates that can alter several problematic petroleum components simultaneously, which are all find in VR.

The microbial decontamination of petroleum-polluted soils seems to be an efficient, economic, and versatile alternative to physicochemical treatments. Several abiotic and biotic parameters including the conditions for microbial degradation activity (e.g., presence of nutrients,

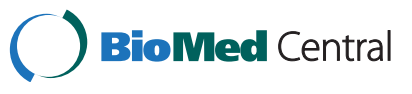


oxygen, $\mathrm{pH}$, and temperature), the quality, quantity, and bioavailability of the contaminants (e.g., particle size distribution), and the soil characteristics, which are hardly to be controlled in the in situ condition, affect the rate of microbial degradation of hydrocarbons in soils $[15,16]$.

Therefore the bacteria with high physicochemical endurance and degradation ability could be a proper choice not only in bioremediation but also in other aspects of oil industry, like heavy oil bio-upgrading or microbial enhanced oil recovery.

Bacteria have several means to overcome the difficulty of complex hydrocarbon uptake. For instance, as bioavailability is the main limitation factor for biodegradation of petroleum hydrocarbons [12,17] due to their chemical structure [18], bacteria produce surfactant to increase bioavailability of PAHs, desorption and solubility of them in the aqueous phase $[18,19]$ and consequently enhance the oil mobility and improving the biodegradation rates [20-22]. Another cell modification leading to new ecotypes may include amendments of the cell envelope to tolerate solvents [23].

Thus to select a useful bacterium for industrial use and bioremediation propose, a sample of soil contaminated with oil for decades in distillation section of Tehran refinery has been screened for bacteria able to degrade and utilize VR ,the most complex structure of petroleum, as its sole source of carbon and energy. Such a bacterium with high environmental endurance and biodegrading a wide range of hydrocarbons could be useful in remediation, heavy crudes bio-upgrading and many other petroleum industry applications.

\section{Methods}

A sample of soil contaminated with crude oil and VR was taken from the field in the distillation unit of Tehran refinery. The soil sample was continuously enriched for a month with VR of Ahvaz crude oil as the sole source of carbon and energy [24,25] in aminimal salt medium (MSM) consisting of $\mathrm{K}_{2} \mathrm{HPO}_{4}, 0.5(\mathrm{~g}) ; \mathrm{NH}_{4} \mathrm{Cl}, 1(\mathrm{~g}) ; \mathrm{Na}_{2} \mathrm{SO}_{4}, 2$ (g); $\mathrm{KNO}_{3}, 2(\mathrm{~g}) ; \mathrm{CaCl}_{2} .6 \mathrm{H}_{2} \mathrm{O}, 0.001(\mathrm{~g}) ; \mathrm{mgSO}_{4} .7 \mathrm{H}_{2} \mathrm{O}, 1(\mathrm{~g})$; $\mathrm{Feso}_{4} \cdot 7 \mathrm{H}_{2} \mathrm{O}, 0.001(\mathrm{~g})$ in 1 liter distilled water $\mathrm{pH} 7.0$ [5]. It was kept under constant agitation at $150 \mathrm{rpm}$ in $30^{\circ} \mathrm{C}$, that was the ambient temperature at the sampling site, for a month with the objective of enriching those microorganisms which can utilize the heavy structure of VR as their sole source of carbon and energy [26]. The sample was enriched because indigenous bacteria in the soil can degrade a wide range of target constituents of the petroleum, but their population and efficiency are affected when any toxic contaminant is present at high concentrations $[27,28]$. This adapted soil indigenous bacterial consortium with VR consisted of several culturable bacteria, isolated by standard plate count method.

\section{Bacterial selection}

Among the isolates the best grown bacteria on VR was chosen for further identification.

The growth and VR-degrading ability of the bacterium studied inminimal salt medium as described, supplementing with $5 \% \mathrm{VR}$ as the sole source carbon and energy [29].

\section{Preculture prepration}

Before each inoculation a primary preculture was prepared as following: $5 \mathrm{ml}$ of the bacterial suspension with optical density equal 1(using T80 UV/VIS spectrometer) enriched in $100 \mathrm{ml}$ nutrient broth; after 48 hours incubation at $30^{\circ} \mathrm{C}$, that was inoculated in MSM supplemented with $5 \%$ VR and $0.1 \%$ glucose as a growth stimulator and agitated for 48hours in $150 \mathrm{rpm}$ at $30^{\circ} \mathrm{C}$, then this preculture was used as inoculum in different experiments. Initially it was inoculated in VR-MSM medium at $30^{\circ} \mathrm{C}$, $150 \mathrm{rpm}$ for 20 days $[29,30]$.

To study the ability of the selected bacteria to degrade both aliphatic [16] and aromatic contents of VR, 1\% Paraffin [29] and $50 \mathrm{mg} / \mathrm{l}$ anthracene [31] both from Merck company production, have been served separately in MSM broth as sole sources of carbon and energy for $48 \mathrm{hrs}$ at $30^{\circ} \mathrm{C}$ in $150 \mathrm{rpm}$.

\section{Sulfur free culture}

The sulfur source of the MSM medium was eliminated (BSM) to investigate the ability of bacteria to acquire its sulfur requirements from $\mathrm{VR}, 1 \mathrm{ml}$ of bacterial suspension has been inoculated in $100 \mathrm{ml} \mathrm{BSM}$ and the growth rate was determined by spectrophotometer at $600 \mathrm{~nm}$ during 20 days of agitation at $150 \mathrm{rpm}$, at $30^{\circ} \mathrm{C}$. BSM consists of $4(\mathrm{~g}) \mathrm{K}_{2} \mathrm{HPO}_{4}, 4(\mathrm{~g}) \mathrm{Na}_{2} \mathrm{HPO}_{4}, 2(\mathrm{~g}) \mathrm{NH}_{4} \mathrm{Cl}, 0.2(\mathrm{~g})$ mgCl. $6 \mathrm{H}_{2} \mathrm{O}, 0.001$ (g) $\mathrm{CaCl}_{2} \cdot 2 \mathrm{H}_{2} \mathrm{O}, 0.001$ (g) $\mathrm{FeCl}_{3} \cdot 6 \mathrm{H}_{2} \mathrm{O}$ in 1 liter distilled water pH7.0 [32].

The probability of utilizing VR as the source of all chemical requirements for bacterial growth was studied by inoculation of $1 \mathrm{ml}$ bacterial suspension $(0.5$ McFarland) in Saline (physiologic serum), supplemented with $5 \% \mathrm{VR}$ and shaking for 20 days at $30^{\circ} \mathrm{C}$ at $150 \mathrm{rpm}$. Saline was used to avoid bacterial destruction at the inoculation stage [29].

Bacterial growth in each media was studied by measuring the bacterial cell population (viable count) and optical density changes at $600 \mathrm{~nm}$ with spectrophotometer (T80 UV/VIS spectrometer). All the experiments were done in triplicate.

\section{Biosurfactant production}

Biosurfactant production was proved by Blood hemolysis [33], drop collapse $[19,34,35]$ and oil spreading techniques [36]. The emulsification ability of the isolate was measured using Krepsley method [17,37]. Emulsification 

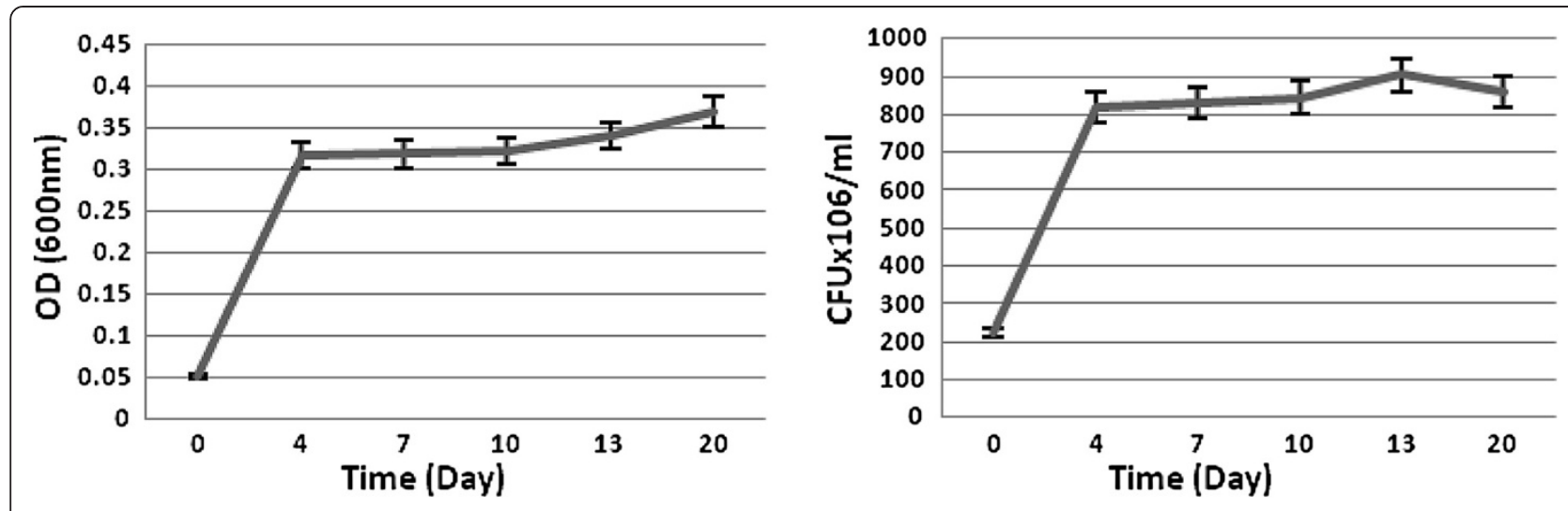

Figure 1 Bacterial growth in MSM broth.

activity was performed both with Iranian light crude oil and n-hexadecane. They were added to bacterial broth in a ratio of 3:2 and then shook for 1minute. After 24 hours rest the height of the emulsified compound was divided by the total height of the system multiplied by 100. Experiments were performed in triplicate for each compound [37].

\section{Hydrophobicity}

The bacterial adhesion to hydrocarbons (BATH) assay was used to determine changes in cell surface hydrophobicity during growth and adaptation with VR in a twenty-day period. The BATH assay was performed as described in literature $[21,38,39]$; however, the washing steps and centrifugation were omitted to avoid cell surfaces damaging [40]. Briefly, $4 \mathrm{ml}$ of bacterial suspension (106 to 107 cells $\mathrm{ml}-1$ ) was vortexed with $1 \mathrm{ml}$ of $\boldsymbol{n}$ hexadecane for at least $2 \mathrm{~min}$. Then the aqueous and hydrocarbon phases were separated in $15 \mathrm{~min}$. One milliliter of the aqueous phase was carefully sampled with a Pasteur pipette. The concentration of cells left in the water phase was determined using Spectrophotometer.
Hydrophobicity (expressed as a percentage) was calculated as follows:

$$
[(a-b) / a] \times 100
$$

where $a$ is the initial cell concentration in the aqueous phase and $b$ is the cell concentration in the aqueous phase after partitioning $[39,41]$. This assay was once done in nutrient broth and simultaneously in the MSM supplemented with VR after incubation period at $30^{\circ} \mathrm{C}$ to determine the hydrophobicity alteration of the bacteria in contact with VR.

\section{Chemical analysis}

VR was extracted with $10 \mathrm{ml}$ Dichloromethane due to its volatility and ability to dissolve a wide range of organic compounds, from aquatic phase of the growth media in a separator y funnel in triplicate. After the solvent's evaporation at room temperature, samples were analyzed. The residue were fractionated into their four principal components - saturates, aromatics, resins, and asphaltenes - commonly known as SARA fractions [42]. The standard method ASTM D4124-01 (2002) was
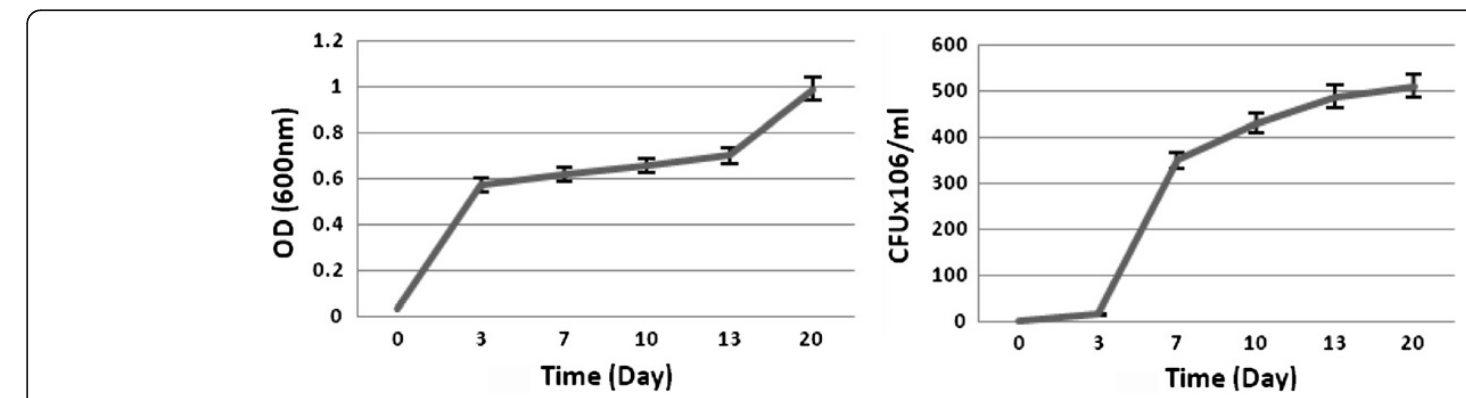

Figure 2 Bacterial growth in BSM broth. 
applied in this study [43]. The sample was first separated into $n$-heptane insoluble asphaltenes and $n$-heptane-soluble petrolenes. Then petrolenes are absorbed on calcined GC-20 alumina and fractioned further into saturates, aromatics and resins by downward solvent elution in a glass chromatographic column. Each assay was performed three times and the average is reported.

\section{Identification}

The selected bacterium was characterized by standard morphological, Gram-reaction, physiological and biochemical techniques [44] and preliminarily identified as a Bacillus sp. The selected Bacillus was identified molecularly through 16SrRNA sequencing. fD1 and rD1 primers (Sinagene/Tehran/Iran) were used for PCR: fD1 ': 5'ccgaattcgtcgacaacagagtttgatcctggctcag3', rD1" :5'ccc gggatccaagcttaaggaggtgatccagcc3'.

Then the PCR product [45] has been cloned in $P$ Bleuescript Sk plasmid. White colonies had been chosen and after confirmation of the presence of 16SrRNA sequence in that, the fragment has been sequenced using $\mathrm{fD} 1$ and $\mathrm{rD} 1$ primers.

\section{Physicochemical endurance}

Effect of temperature on the isolate was studied using $100 \mathrm{mlmineral}$ salt medium with $5 \mathrm{ml} \mathrm{VR}$ and $1 \mathrm{ml}$ preculture at pH6.8 on shaker at $150 \mathrm{rpm}$ for $48 \mathrm{hrs}$. Then the $\mathrm{pH}$ and salinity endurance of the bacteria in MSM broth at $150 \mathrm{rpm}$ for $48 \mathrm{hrs}$ was respectively studied [31].

All experiments were done in triplicate at the adaptation temperature $\left(30^{\circ} \mathrm{C}\right)$ and in a short period of 20days (for biodegradation). To analyze the biodegradation an un-inoculated flasks with VR were served as control under each experiment condition.

\section{Results}

Bacterial growth inminimal medium supplemented with vacuum residue was evident from the significant increase in the population as compared to control by measuring cell density at $600 \mathrm{~nm}$ and alternate colony counting, both in 20 days of incubation period [46]. The bacterium which could more efficiently transform the rough appearance of VR in shorter time and could tolerate the toxicity of it with better growth rate in different growth media, was chosen for further identification.

The selected isolate grew continuously and the turbidity increased during 20 days (Figure 1), and the rough and rigid appearance of VR changed during the incubation period into small globular structures. Values represent the average of three experiments.

Bacterial growth was studied in sulfur free medium (Figure 2). A considerable turbidity was reported in saline supplemented with VR after shaking at 150rpm and $30^{\circ} \mathrm{C}$ (Figure 3).

The emulsification activity of the bacterium was $10.2 \%$ in n-hexadecane and 7\% in crude oil. The drop collapse test, oil spreading technique with $50 \mathrm{~mm}$ diameter clear zone and RBC hemolysis with over $75 \mathrm{~mm}$ diameter clear zone in 24 hours confirmed the biosurfactant production $[19,47]$ (Figure 4).

The hydrophobicity of the bacterial cells was $10.99 \%$ before incubation with VR and it had increased to $16.67 \%$. The percentages are the average of triplicate experiments.

The result of VR chemical analysis for the percentage of alkanes, aromatics, asphaltenes and resins, using SARA test after 20 days treatment with the bacterium in different media, is illustrated in Figure 5.

The selected bacterium was able to grow in a wide range of $\mathrm{pH}$ from 5.5 to 8 , salinity up to $3 \%$ and temperature from $20^{\circ} \mathrm{C}$ to $55^{\circ} \mathrm{C}$.

Bacterial growth was observed both in MSM broth supplied with anthracene or with paraffin by medium turbidity after 48 hours.

Biochemical (Table 1) and Molecular analysis defined the selected bacterium as a novel strain of Bacillus cereus. This bacterium accession number in GenBank is appeared as JQ178332.

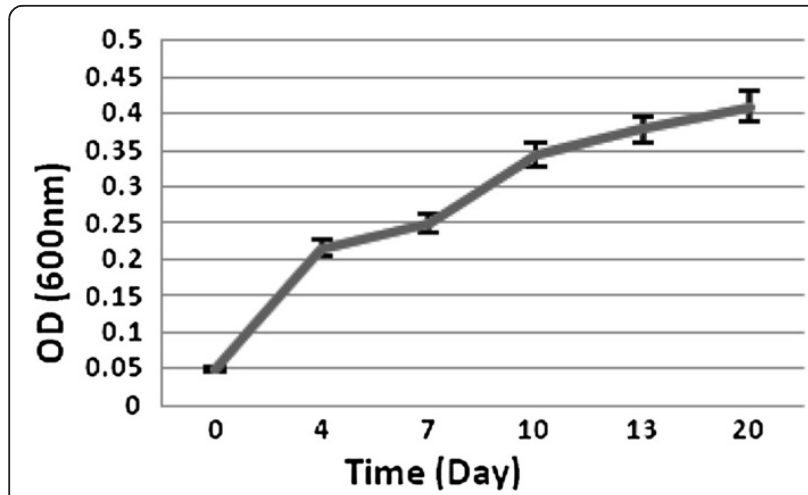

Figure 3 Bacterial growth in saline.

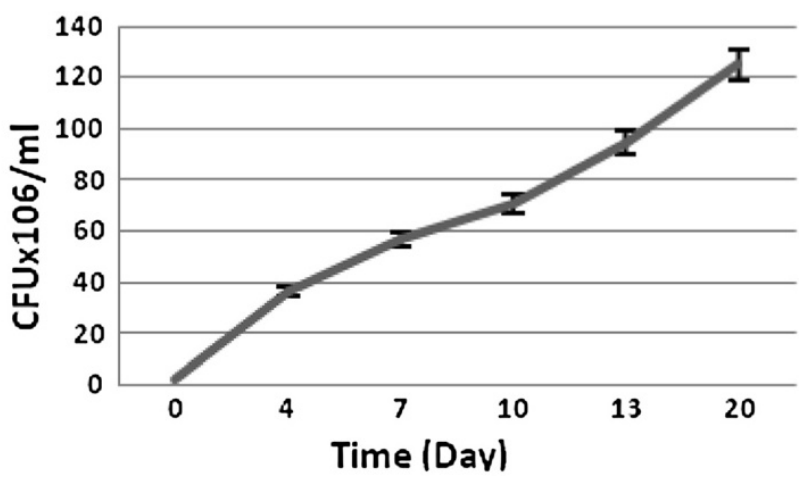




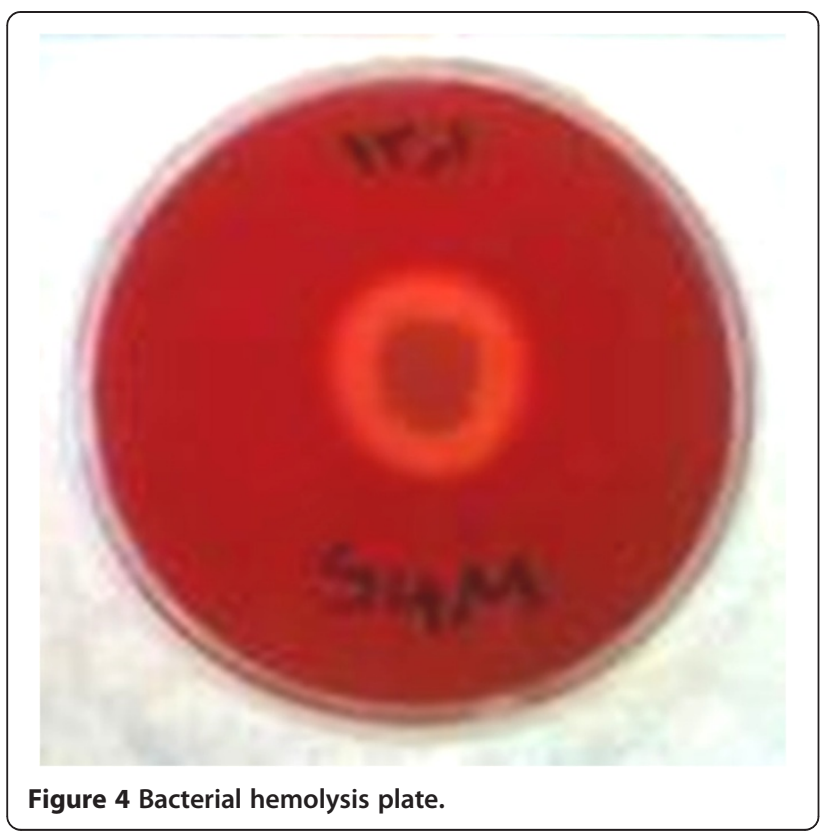

\section{Discussion}

This study indicated that there are bacteria able to biodegrade complexes of both aliphatic and aromatic hydrocarbon in extreme nutritional conditions along with each other in only presence of water. This finding could be a useful approach in environmental biotechnology.

Several studies have already proved the ability of Bacilli in degradation of various structures of hydrocarbons $[30,46,48,49]$ but there are rare information of vacuum distillation residue, containing both asphaltene and wax, degradation.

Molecular analysis of the selected, spore forming, biosurfactant producing bacterium as a novel strain of Bacillus cereus (JQ178332) in this study, ascribed this bacterium with $94 \%$ similarity to Bacillus cereus Q1
Table 1 Biochemical tests of selected bacterium

\begin{tabular}{cc}
\hline Tests & Selected bacterium \\
\hline Gram staining & + \\
Spore staining (malachite green) & + \\
Catalase & + \\
Citrate & S $(-)$, Movement $(+)$ \\
SIM & + \\
Starch hydrolysis & + \\
lecithinase & +
\end{tabular}

(CP000227.1), previously described as a thermopile bacterium by Xiong et.al 2009 from deep oil reservoir [49].

As VR content analysis illustrates, there is $22.1 \%$ decrease in saturate alkanes, $30.3 \%$ in Aromatics, and 65.5\% in Asphaltenes percentage and remain of resin as the last bacterial invaded component when VR treated with selected bacterium in $30^{\circ} \mathrm{C}$ in $150 \mathrm{rpm}$ shaking for 3 weeks in MSM [14].

\section{Conclusion}

The high physicochemical endurance of Bacillus cereus isolated from petroleum contaminated soil with the ability to utilize both aliphatic and complex aromatic structures of distillation residual substances as its sole source of carbon and energy, and the particular finding of this research that revealed the remarkable ability of the bacterium to use VR as the only source of all required chemicals for growth along with surfactant production, make this bacterium a unique option for industrial use, particularly in bioremediation, bio-upgrading and biorefining processes. This bacterium with ability to biodegrade and utilize heavy fractions of vacuum distillation residue as its sole source of carbon and energy can be useful in petroleum biological processing with less severe condition to increase net distillates.

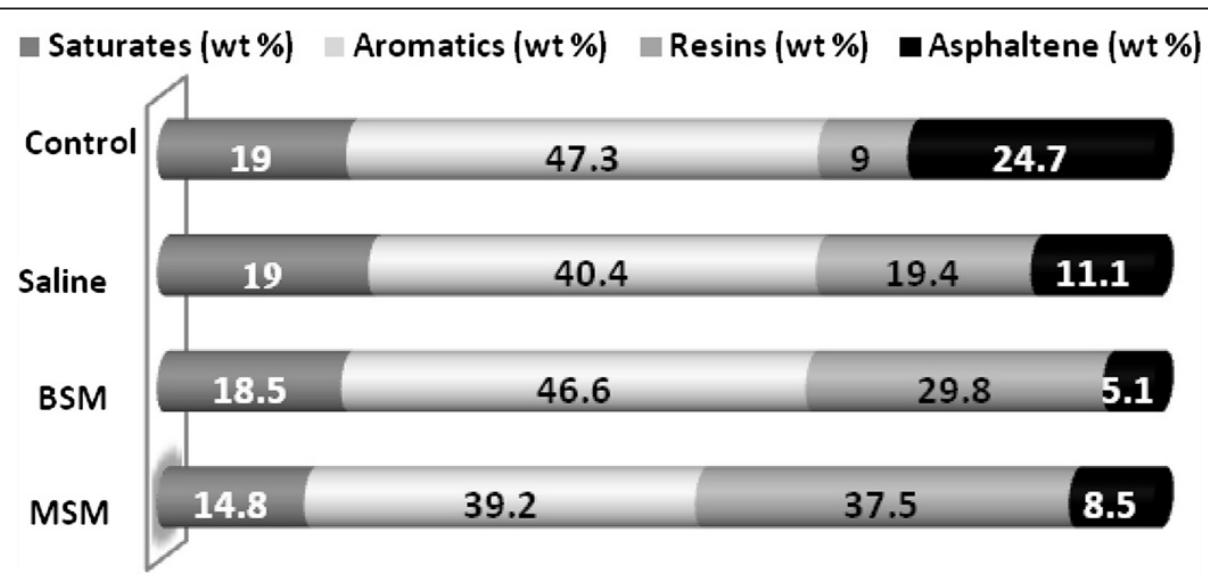

Figure 5 SARA content weight percent. 


\section{Competing interests}

The authors declare that they have no competing interests.

\section{Authors' contributions}

MMA was the project principle investigation and supervisor to MST during her PhD thesis. MST was the PhD scholars in above said project. The work is a part of her PhD thesis. Both authors read and approved the final manuscript.

\section{Authors' information}

The first author contributed as PhD scholar and second author as supervisor, to this work.

\section{Acknowledgements}

This research was jointly supported by Iranian Research Organization for Science and Technology, Tehran, Iran and Islamic Azad University, central Tehran Branch, Tehran, Iran.

\section{Author details}

'Department of Biology, Faculty of Science, Islamic Azad University, Central Tehran branch, Tehran, Iran. ${ }^{2}$ Environmental Biotechnology, Biotechnology Department, Iranian Research Organization for Science and Technology, Tehran, Iran.

Received: 25 July 2012 Accepted: 2 July 2013

Published: 16 July 2013

\section{References}

1. Khorasani AC, Mashreghi M, Yaghmaei S: Study on biodegradation of mazut by newly isolated strain Enterobacter cloacae BBRC10061:improving and kinetic investigation. Iranian J Environ Health Sci Eng 2013, 10:2.

2. Krieg W: Bergey's Manual of systematic. In Bacteriology. 1st edition. Edited by Holt NR, Williams JG. 1984:140-310.

3. Liu W, Luo Y, Teng Y, Li ZQ, Ma L: Bioremediation of oily sludge contaminated soil by stimulating indigenous microbes. Environ Geochem Health 2010, 32(1):23-29.

4. Kim JS, Crowley DE: Microbial diversity in natural asphalts of the rancho La Brea Tar pits. Appl Environ Microbiol 2007, 73(14):4579-459.

5. Pendrys JP: Biodegradation of asphalt cement-20 by aerobic bacteria. Appl Environ Microbiol 1989, 55(6):1357-1362.

6. Liu Y, Gao L, Wen L, Zong B: Recent advances in heavy Oil hydroprocessing technologies. Recent Patents Chemical Engineering 2009, 2:22-36

7. Pineda-Flores G, Mesta-Howard AM: Petroleum asphaltenes: generated problematic and possible biodegradation mechanisms. Rev Latinoam Microbiol 2001, 43(3):143-150.

8. Sood N, Lal B: Isolation and characterization of a potential paraffin-wax degrading thermophilic bacterial strain Geobacillus kaustophilus TERI NSM for application in oil wells with paraffin deposition problems. Chemosphere 2008, 70:14451451.

9. Vazquez-Duhalt R, Quintero-Ramirez R: Prospects for biological upgrading of heavy oils and asphaltenes, Petroleum Biotechnology: Developments and Perspectives. 4th edition. The Netherlands: ELSEVIER B.V; 2004:113-143.

10. Wang XB, Chi CQ, Nie Y, Tang YQ, Tan Y, Wu G, Wu XL: Degradation of petroleum hydrocarbons (C6-C40) and crude oil by a novel Dietzia strain. Bioresource Technol 2011, 102(17):7755-61.

11. Karimi A, Golbabaei F, Neghab M, Reza PM, Nikpey A, Mohammad K, Mehrnia MR: Biodegradation of high concentrations of benzene vapors in a two phase partition stirred tank bioreactor. Iranian J Environ Health Sci Eng 2013, 10:10.

12. Kim IS, Park J, Kim KW: Enhanced biodegradation of polycyclic aromatic hydrocarbons using nonionic surfactants in soil slurry. Appl Geochem 2001, 16:1419-1428.

13. Östberg TL, Jonsson AP, Lundström US: Enhanced degradation of $n$-hexadecane in diesel fuel contaminated soil by the addition of fermented whey. Soil Sediment Contamination 2007, 16(2):221-232.

14. Whyte IG, Bourbonniere I, Greer CW: Biodegradation of petroleum hydrocarbons by psychrotrophic pseudomonas strains possessing both alkane (alk) and naphthalene (nah) catabolic pathways. Appl Environ Microbiol 1997, 63(9):3719-3723.
15. Margesin R, Schinner F: Efficiency of indigenous and inoculated coldadapted soil microorganisms for biodegradation of diesel oil in Alpine soils. Appl Environ Microbiol 1997, 63(7):2660-2664

16. Wang Q, Zhang S, Li Y, Klassen W: Potential approaches to improving biodegradation of hydrocarbons for bioremediation of crude oil pollution. J Environ Protect 2011, 2:47-55.

17. Banat IM: Biosurfactants production and possible uses in microbial enhanced oil recovery and oil pollution remediation: a review. Biosource Tech 1995, 51:1-12.

18. Makkar RS, Rockne KJ: Comparison of synthetic surfactants and biosurfactants in enhancing biodegradation of polycyclic aromatic hydrocarbons. EnvironToxicol Chem 2003, 22(10):2280-2292.

19. Mazaheri Assadi M, Tabatabaee MS: Biosurfactants and their Use in upgrading petroleum vacuum distillation residue: a review. Inter I Environ Res 2010, 4(4):549-572.

20. Barathi S, Vasudevan N: Utilization of petroleum hydrocarbons by Pseudomonas fluorescens isolated from a petroleum-contaminated soil. Environ inter 2001, 26:413-416.

21. Rosenberg E, Rubinovitz C, Gottlieb A, Rosenhak S, Ron EZ: Production of biodispersan by Acinetobacter calcoaceticus A2. Appl Environ Microbiol 1988, 54:317-322.

22. Sar N, Rosenberg E: Emulsifier production by Acinetobacter calcoaeticus strains. Current Microbiol 1983, 9:309-314.

23. Ramos JL, Duque E, Gallegos MT, Godyoy P, Ramos-Gonzalez MI, Rojas A, Teran W, Segura A: Mechanisms of solvent tolerance in gram-negative bacteria. Annual Rev Microbiol 2002, 56:743-768.

24. Tabatabaee A, Mazaheri Assadi M: Methanogenic life in extreme condition of Oil reservoir. Environ Sci 2005, 10:51-58.

25. Tabatabaee A, Mazaheri Assadi M, Noohi AS, Sadjadian H: Isolation and identification of MEOR from Iranian reservoir. Inter J Environ Health Sci Eng 2005, 2(1):6-12.

26. Maciel BM, Santos ACF, Dias JCT, Vidal RO, Dias RJC, Gross Cascardo EJCM Rezende RP: Simple DNA extraction protocol for a 16S rDNA study of bacterial diversity in tropical land farm soil used for bioremediation of oil waste. Genetics Molular Res 2009, 8(1):375-388.

27. Eriksson M, Dalhammar G, Borg-Karlson AK: Aerobic degradation of a hydrocarbon mixture in natural uncontaminated potting soil by indigenous microorganisms at $20^{\circ} \mathrm{C}$ and $6^{\circ} \mathrm{C}$. Appl Microbiol and Biotech 1999, 51:532-535.

28. Mishra S, Jyot J, Kuhad RC, Lal B: Evaluation of inoculum addition to stimulate in situ bioremediation of oily-sludge-contaminated soil. Appl Environ Microbiol 2001, 67(4):1675-1681.

29. Tabatabaee MS, Mazaheri Assadi M, Heydarian M, Akhavan Sepahi A: Soil microbial degradation of vacuum residue. Petrol Sci Tech 2012, 30:1-9.

30. Akhavan Sepahi A, Mazaheri Asadi M, Saggadian V, Nouhi AS: Production of biosurfactant from Iranian Oil fields by isolated bacilli. Inter J EnvironSci Technol 2005, 1(4):287-294.

31. Kastner M, Breuer-Jammali M, Mahro B: Impact of inoculation protocols, salinity, and ph on the degradation of polycyclic aromatic hydrocarbons and survival of pah-degrading bacteria introduced into soil. Appl Environ Microbiol 1998, 64(1):359-362.

32. Wang $P$, Krawiec $S$ : Desulfurization of dibenzothiophene to 2 hydroxybiphenyl by some newly isolated bacterial strains. Arch Microbiol 1994, 161:266-271

33. Balogun $S A$, Fagade OE: Screening for surface-active agent producing bacteria from diesel oil polluted tropical soil. World App/ Sci J 2008, 3(6):930-933.

34. Tugrul T, Cansunar E: Detecting surfactant-producing microorganisms by the drop-collapse test. World J Microbiol Biotech 2005, 21:851-853.

35. Bodour AA, Miller-Maier RM: Application of a modified drop-collapse technique for surfactant quantization and screening of biosurfactant-producing microorganisms. J Microbiol Methods 1998, 32(3):273-28

36. Mclnerney MJ, Youssef N, Fincher T, Maudgalya SK, Folmsbee MJ, Knapp G, Nagle D: Development of Microorganisms with Improved Transport and Biosurfactant Activity for Enhanced Oil Recovery. University of Oklahoma: Department of Botany and Microbiology and Department of Petroleum Engineering University of Oklahoma,Annual Report; 2004:22-23.

37. Krepsky N, Da Silva FS, Fontana LF, Crapez M: Alternative methodology for isolation of biosurfactant-producing bacteria. Brazilian J Biol 2007, 67(1):117-124 
38. Rosenberg M, Gutnick D, Rosenberg E: Adherence of bacteria to hydrocarbons: a simple method for measuring cell surface hydrophobicity. FEMS Microbiol Let 1980, 9:29-33.

39. Matz C, Jürgens K: Effects of hydrophobic and electrostatic cell surface properties of bacteria on feeding rates of heterotrophic nanoflagellates. Appl Environ Microbiol 2001, 67(2):814-820.

40. Pembrey RS, Marshall KC, Schneider RP: Cell surface analysis techniques: what do cell preparation protocols do to cell surface properties. Appl Environ Microbiol 1999, 65:2877-2894.

41. Pruthi VC, Cameotra SS: Rapid identification of biosurfactant-producing bacterial strains using a cell surface hydrophobicity technique. Biotechnol Techniques 1997, 11(9):671-674.

42. Peralta-Martinez MV, Vazquez-Ramirez R, Blass-Amador G, Palacios-Lozano EM: Determination of functional groups in Mexican vacuum residua. Petrol Sci Techniques 2008, 26(1):91-100.

43. ASTM D4124-01: Standard test method for separation of asphalt into four fractions. Annual book of ASTM standard, 4.03. Philadelphia: ASTM; 2002

44. Leon V, Cumar M: Biological upgrading of heavy crude oil. Biotech Bioprocess Eng 2005, 10:471-481.

45. Weisburg WG, Barns SM, Pelletier DA, Lane DJ: 16S ribosomal DNA amplification for phylogenetic study. J Bacterio/ 1991, 173(2):697-703.

46. Das K, Mukherjee AK: Crude petroleum-oil biodegradation efficiency of Bacillus subtilis and Pseudomonas aeruginosa strains isolated from a petroleum-oil contaminated soil from North-East India. Bioresource Tech 2007, 98(7):1339-1345.

47. Vasileva-Tonkova E, Gesheva V: Biosurfactant production by antarctic facultative anaerobe pantoea sp. during growth on hydrocarbons. Current Microbiol 2007, 54(2):136-141.

48. Haghighat S, Akhavan Sepahy A, Mazaheri Assadi M, Pasdar H: Ability of indigenous Bacillus licheniformis and Bacillus subtilis in microbial enhanced Oil recovery. Inter J of Environ sci technol 2008, 5(2):385-390.

49. Xiong Z, Jiang Y, Qi D, Lu H, Yang F, Yang J, Chen L, Sun L, Xu X, Xue Y, Zhu Y, Jin Q: Complete genome sequence of the extremophilic Bacillus cereus strain Q1 with industrial applications. J bacterial 2009, 191:1120-1121.

doi:10.1186/2052-336X-11-18

Cite this article as: Tabatabaee and Mazaheri Assadi: Vacuum distillation residue upgrading by an indigenous Bacillus cereus. Journal of Environmental Health Sciences \& Engineering 2013 11:18.

\section{Submit your next manuscript to BioMed Central and take full advantage of:}

- Convenient online submission

- Thorough peer review

- No space constraints or color figure charges

- Immediate publication on acceptance

- Inclusion in PubMed, CAS, Scopus and Google Scholar

- Research which is freely available for redistribution 